\title{
履歴型ダンパーを有する超高層制振建物の風応答時における累積損傷分布予測 \\ CUMULATIVE DAMAGE PREDICTION FOR PASSIVE CONTROLLED HIGH-RISE BUILDING WITH HYSTERETIC DAMPERS ON WIND-INDUCED RESPONSE
}

\author{
佐藤大樹*1, 池上昌志 ${ }^{* 2}$, 平井宏幸*3, \\ 吉江 慶祐 ${ }^{* 4}$, 佐藤利 昭 ${ }^{* 5}$, 北村春幸*6 \\ Daiki SATO, Masashi IKEGAMI, Hiroyuki HIRAI, \\ Keisuke YOSHIE, Toshiaki SATO and Haruyuki KITAMURA
}

\begin{abstract}
An energy balance-based design method for earthquake-induced response of a building has been proposed by Dr. Akiyama; it is very useful for the evaluation of the cumulative damage. However, an energy balance-based design method for the wind-induced response of buildings has not been established yet. In this study, we establish a prediction method based on energy balance for estimating the cumulative damage to hysteretic dampers installed in a high-rise building on wind-induced response. We propose a new optimum yield shear force coefficient distribution and damage concentration factor for prediction of damage caused by wind-induced response. The validity of this prediction method is confirmed by comparing the results with time history analysis results.
\end{abstract}

Keywords : Passive Controlled High-rise Building, Elasto-plastic Wind-induced Response, Hysteretic Damper, Cumulative Damage Prediction, Energy Balance 超高層制振建物，弾塑性風応答，履歷型ダンパー，累積損傷予測，エネルギーの釣合

1. はじめに

地震時における超高層建物の構造体の損傷制御, あるいは応答低 減を目的として, 建物内に履歴減衰型または粘性減衰型のダンパー により減衰を付加する制振構造は寸でに広く普及している ${ }^{4)}$ 。鋼材 ダンパーに代表される履歴減衰型ダンパーの場合, 制振効果を高め るためには，できるだけ小さな荷重レベルから早期にダンパーを塑 性化させることで，エネルギー吸収を積極的に行うことが有効であ る。ただし, 超高層建物に履歴減衰型ダンパーを採用した制振構造 を設計する場合には，長周期・長時間地震やその余震によって発生 する, 多数回の繰返しによるダンパーの累積疲労損傷を評価する必 要がある ${ }^{5), 6)}$ 。

一方, 現状の耐風設計では, 建築物の高層化が進み, 風荷重が構 造設計において支配的な設計荷重となる建築物が出現するようにな っても，想定される最大の風荷重に対して主要な構造体を弾性応答 に留めるように設計が行なわれている。これは，風外力の継続時間 が数時間に及ぶため, 部材や接合部などに累積疲労損傷の恐れがあ ること, 塑性化によって建築物の固有周期が長くなると, 風力が長 周期側にパワーのピークを持つため, 固有周期に対応する風外力の
パワーが増し，風荷重が増大する恐れがあること，また，それらに 対する研究が十分に進んでいないなどの理由によるものである7)。 しかし，地震に対する制振効果を高めるために，低い荷重レベルで 塑性化させる履歴減衰型ダンパーを採用すると, 風外力によってダ ンパーが塑性化することが考えられる。このような場合，風荷重に 対してもダンパーの累積疲労損傷の評価が必須となる。

弾塑性風応答時におけるダンパーの累積疲労損傷を評価するため に，一般的には時刻歴応答解析を行なう必要がある例えば8)。その際， 地震動と比較して遙かに継続時間の長い風外力を用いて, 多数の時 刻歴応答解析を行なうモンテカルロ法を用いる必要があるので，膨 大な計算量を必要とする。そのため, 風荷重に対する弾塑性風応答 時における建物の挙動を把握するだけでなく, 履歴減衰型ダンパー の累積疲労損傷を実用的に評価するために，時刻歷応答解析を用い ない手法が求められている ${ }^{9), 10)}$ 。特に, 累積疲労損傷と直接に関連付け ることができるエネルギ一の釣合に基づく評価は有用であると考えられ， 吉江らはエネルギーの釣合を利用した 1 質点系弾塑性モデルにおけ る弾塑性風応答予測手法を提案している ${ }^{10)}$ 。ただし, 実際の構造物 の設計に応用するためには, 多質点系での弾塑性風応答予測方法が
本論文は，文献 1)～3)の内容に加筆・修正したものである。

*1 東京工業大学未来産業技術研究所 准教授 · 博士 (工学)

*2 前田建設工業(株) 修士 (工学) (元 東京理科大学大学院)

*3 戸田建設侏) 修士 (工学) (元 東京理科大学大学院)

*4 (株)日建設計 構造設計部長·博士 (工学)

* 5 九州大学大学院人間環境学研究院 准教授・博士 (工学)

*6 東京理科大学理工学部建築学科 教授 · 博士 (工学)
Assoc. Prof., FIRST, Tokyo Institute of Tech., Dr.Eng.

MAEDA Corporation, M.Eng. (Former Grad. Stud., Tokyo Univ. of Science)

TODA Corporation, MEng. (Former Grad. Stud, Tokyo Univ, of Science)

General Manager, Structural Engineering Section, Nikken Sekkei Ltd., Dr.Eng.

Assoc. Prof., Faculty of Human-Environmental Studies, Kyushu Univ., Dr.Eng.

Prof., Dept. of Architecture, Tokyo Univ. of Science, Dr.Eng. 
必要である。その方法の 1 つとして, 耐震設計の分野で秋山によっ て提案されているエネルギーの釣合に基づく耐震設計法（以下，エ ネルギー法）11)を，風応答時にも適用することが考えられる。

エネルギー法により, 変形や塑性化の度合いと履歴吸収エネルギ 一を直接に関係つけることで, 時刻歴応答解析を用いることなく各 層の累積損傷評価や応答予測を行うことが可能となる。エネルギー 法を用いて応答予測を行なうためには, 入力されたエネルギーが各 層にどの程度配分されるか, つまりエネルギーの高さ方向の分布 (以 下, 累積損傷分布）を予測する必要がある。秋山が提案した累積損 傷分布の予測式は, 設定した各層のせん断力が, 累積塑性変形倍率 が全層で等しくなる理想的な降伏せん断力分布である「最適降伏せ 几断力係数分布 $\left.\bar{\alpha}_{i}\right\lrcorner$ からずれに基づいて算出され, 損傷集中の程 度は「損傷集中指数 $\left.n_{s}\right\rfloor$ にって表される ${ }^{11)}$ 。しかし, 秋山によっ て提案された最適降伏せん断力係数分布 $\bar{\alpha}_{i}$ や損傷集中指数 $n_{s}$ は地 震応答を対象に決定された值であり ${ }^{11,12)}$, 風応答に対する適用を検 討した研究はこれまでに無い。地震外力と風外力に対して, エネル ギー法により統一的に累積損傷分布を予測することができれば，設 計時においてダンパーの累積疲労損傷を, 地震だけでなく風応答も 含めて総合的に評価することが可能となる。

本論文では，エネルギーの釣合に基づく履歴減衰型ダンパー（以 下，ダンパーと呼ぶ）を有する超高層制振建物の弾塑性風応答予測 手法を構築するための第 1 段階として, 累積損傷分布の予測手法を 構築することを目的とし, 最適降伏せん断力係数分布 $\bar{\alpha}_{i}$ や損傷集中 指数 $n_{s}$ を新たに提案する。弾塑性風応答は地震応答と異なり, 風力 がもつ平均成分 ${ }^{9), 10)}$ の影響を受けることは既に知られているが，本 論文は平均成分の影響を別途考慮するものとして ${ }^{9}$, 変動成分のみ の風方向風力と風直交方向風力を対象とした累積損傷分布の予測手 法を提案するものである。風外力に平均成分を有する場合や風方 向・風直交方向・捻孔が同時に作用した場合の累積損傷分布につい ては今後の課題とする。

以下に本論文の構成を示す。第 2 章では, 多数のパラメータを幅 広く変化させた数值実験結果から, 風応答時の最適降伏せん断力係 数分布の特徴を述べ, 地震応答時の最適降伏せ几断力係数分布と比 較する。第 3 章では, スペクトルモーダル解析により, 時刻歴応答 解析を用いずに風応答時の最適降伏せん断力係数分布を算出する手 法を提案する。第 4 章では, 数值実験から算出した風応答時の損傷
集中指数が地震時と比較した後, 風応答時の損傷集中指数を新たに 提案する。さらに, 提案した最適降伏せん断力係数分布と損傷集中 指数を用いて風応答時におけるダンパーの累積損傷分布を予測し, 時刻歴応答解析結果と比較することで, 本手法の予測精度と適用範 囲についての検証を行なう。なお, 本論文では構造物の振動により 風力特性が変化しないことを前提として, 空力不安定振動の問題は 対象外とする。

\section{2. 風応答時における最適降伏せん断力係数分布の検討}

秋山により提案されている地震応答を対象としたエネルギー法で は, 累積損傷予測に用いられる最適降伏せん断力係数分布 $\bar{\alpha}_{i}$ を, 弾 性モデルの最大応答せん断力係数分布で表現している ${ }^{11)}$ 。本章でも, その手法を準用し, フレームのタイプ, ダンパー量, ダンパーの剛 性および降伏せん断力をパラメータとした時刻歴風応答解析による 数值実験から風応答時の最大応答せん断力係数分布を算定し, 地震 応答時の最適降伏せん断力係数分布 $\bar{\alpha}_{i}$ と比較検討を行なう。さらに 算定した風応答時の最大応答せん断力係数分布を用いることで, 累 積塑性変形倍率が全層で等しくなる状態（以下，基準状態と呼ぶ） を満たすかを検証し, 風応答時においても最適降伏せん断力係数が 存在するかを確認する。

\section{1 解析対象モデルの概要}

検討対象建物の解析モデルを図 1 に示す。本論文では, 超高層制 振建物を対象とし, 高さ $H=200 \mathrm{~m}$ の 10 質点せん断型モデルを用い る。フレームを, 1 次固有周期 ${ }_{f 1} T=5.0 \mathrm{~s}$, 建物密度 ${ }_{f} \rho=175 \mathrm{~kg} / \mathrm{m}^{3}$ とし, 質量は高さ方向に一様と想定した。辺長比 $D / B$ を, 図 2 に示 すような $D / B=1.0,2.0,3.0$ の 3 種類とする。なお, 全ての $D / B$ に 対して平面積を $1,600 \mathrm{~m}^{2}$ としているため, $D / B$ ごとにそれぞれ $B, D$ が異なる（表 1)。構造減衰を剛性比例型として, ${ }_{f 1} T$ に対して, 減衰 定数 ${ }_{f 1} h=0.01,0.02,0.05$ の 3 種類を用いる。各層のフレーム剛性 ${ }_{f} k_{i}$ は, 建物の 1 次固有モードが直線 ${ }^{13)}$ となる F1 frame と, ${ }_{f} k_{10}=0.5{ }_{f} k_{1}$ の台形分布となり， かつ ${ }_{f 1} T=5.0 \mathrm{~s}$ となるよう設定した F 2 frame $の 2$ 種類を用いた（図 3(a)）。本論文ではダンパーを完全弾塑性としてモ デル化し, 全層で用いている。各層のダンパー剛性 ${ }_{d} k_{i}$ は, ${ }_{d} k_{i} /{ }_{f} k_{i}$ を 各層一定の ${ }_{d} k_{i} /{ }_{f} k_{i}=1.0$ とした D 1 type と, 1 層で ${ }_{d} k_{1} /{ }_{f} k_{1}=1.0,10$ 層で ${ }_{d} k_{10} /{ }_{f} k_{10}=0.5$ の台形分布となる D2type の 2 種類を用いた（図 3 (b))。なお, ダンパーとフレームを合せてシステムと呼び, ダンパ

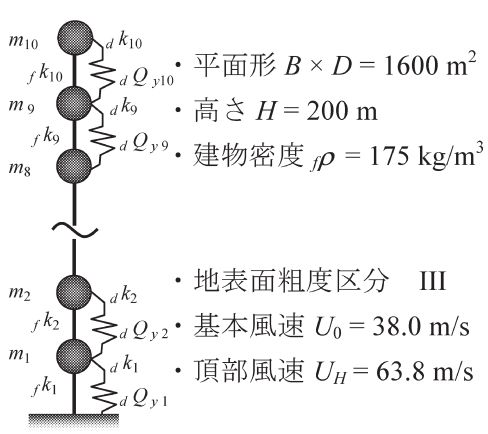

図 1 弾塑性解析モデル概要

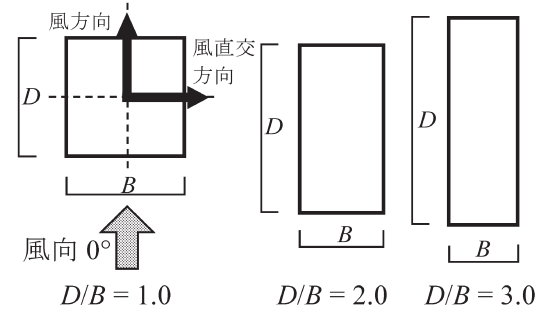

図 2 風向の定義および辺長比

\begin{tabular}{|c|c|c|}
\hline 表 1 & \multicolumn{2}{|c|}{ 辺長比一覧 } \\
\hline$D / B$ & $B(\mathrm{~m})$ & $D(\mathrm{~m})$ \\
\hline 1.0 & 40.0 & 40.0 \\
\hline 2.0 & 28.3 & 56.6 \\
\hline 3.0 & 23.1 & 69.3 \\
\hline
\end{tabular}

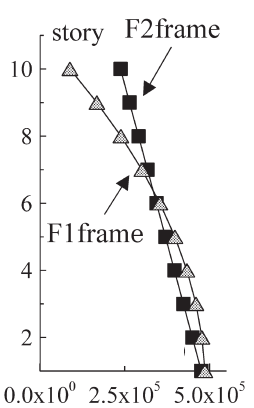

${ }_{f} k_{i}(\mathrm{kN} / \mathrm{m})$

(a) フレーム

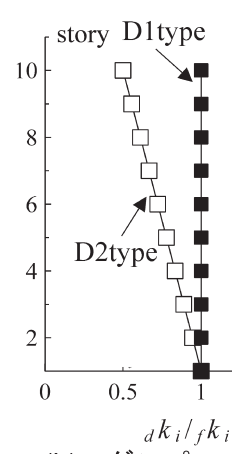

(b) ダンパー

図 3 剛性分布 


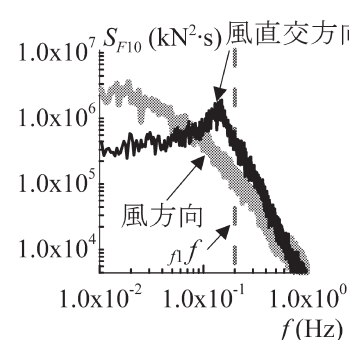

(a) $D / B=1.0$

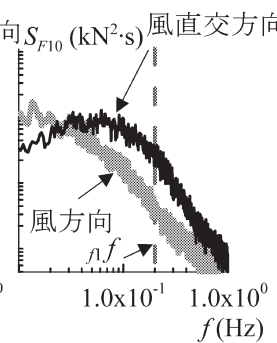

(b) $D / B=2.0$

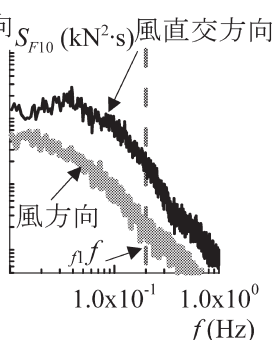

(c) $D / B=3.0$

図 4 頂部層風カのパワースペクトル密度

一を弾性としたモデルを弾性モデルと呼ぶ事とする。ダンパーの降 伏せん断力の設定については後述する。固有值解析より求めたシス テムの弾性 1 次固有周期 $1 T$ は, F1D1model と F2D1model が ${ }_{1} T=3.54$ s, F1D2model は ${ }_{1} T=3.76 \mathrm{~s}$, F2D2model は $1 T=3.65 \mathrm{~s}$ である。

\section{2 風外力の概要および応答の評価方法}

構造物に作用する風外力は風洞実験結果 ${ }^{14)}$ を用いた。実験気流を 「建築物荷重指針・同解説」 ${ }^{15)}$ の地表面粗度区分 III の気流を目標に 作成した。実験模型は高さ $H=50 \mathrm{~cm}$, 辺長比 $D / B=1.0,2.0,3.0$, 平面積 $A=100 \mathrm{~cm}^{2}$ の角柱模型とし, 層風力を 10 層分測定した。風 洞実験方法および実験条件の詳細については文献 14)を参照された い。時刻歴風応答解析には, 「建築物荷重指針・同解説」 ${ }^{15}$ に従って 算出した再現期間 500 年に相当する風力（頂部風速 $U_{H}=63.8 \mathrm{~m} / \mathrm{s}$ ) を用いた。検討用風力波形は 1 組につき 10 質点分の変動風力波形を $0.05 \mathrm{~s}$ 刻み 13,000 ステップとし, 風洞実験結果から応答の評価時間 部分が重ならないように $650 \mathrm{~s} \times 30$ 組を取り出した。本論文では, 風向角 $0^{\circ}$ で $D / B=1.0,2.0,3.0$ の合計 6 種類の特性の異なる風力 を用いる。

本論文では前述したように，平均成分を含まない変動成分のみの 風方向風力と風直交方向風力を対象としている。図 $4(\mathrm{a}) \sim(\mathrm{c})$ に風方 向風力, 風直交方向の層風力の例として, 頂部層風力 $F_{10}$ のパワー スペクトル密度 $S_{F 10}$ を辺長比 $D / B$ ごとに示す。なお, 図 4 に示す $S_{F 10}$ は 30 波のアンサンブル平均結果である。図中の破線はフレームのみ での弾性 1 次固有振動数 $f f$ である。図 4 より, 風方向風力において $D / B$ の差異によらず, 解析モデルの 1 次固有振動数に比べて低振動 数側で大きなパワーを有するスペクトル形状であり準静的成分（後 述）が多く含まれていることが確認できる。風直交方向風力の $D / B=$ 3.0 においても風方向風力と同様に, 低振動数側に大きなパワーを 有する広帯域なスペクトル形状であるが， $D / B$ が小さくなるのに従 って, $0.1 \mathrm{~Hz}$ 付近にピークをもつ。特に $D / B=1$ では, 比較的狭帯 域なスペクトル形状となることがわかる。このように，本論文では 変動成分による風応答を考える上で, 幅広い検討が行えるように風 力を決定している。

時刻歷風応答解析開始時における過渡応答の影響を避けるため, 各風力波形の先頭 $50 \mathrm{~s}$ にエンベロープを設け，その後の $600 \mathrm{~s} （ 10$ 分）間での応答を評価に用いる。本論文では 30 波 ${ }^{16)}$ のアンサンブ ル平均により応答值を評価する。

\section{3 風応答時における弾性モデルの最大応答せん断力係数分布}

弹性モデルを用いた時刻歴応答解析結果から，風応答時の最大応 答せん断力係数分布 $\alpha_{i} / \alpha_{1}$ を式(1)より求める。
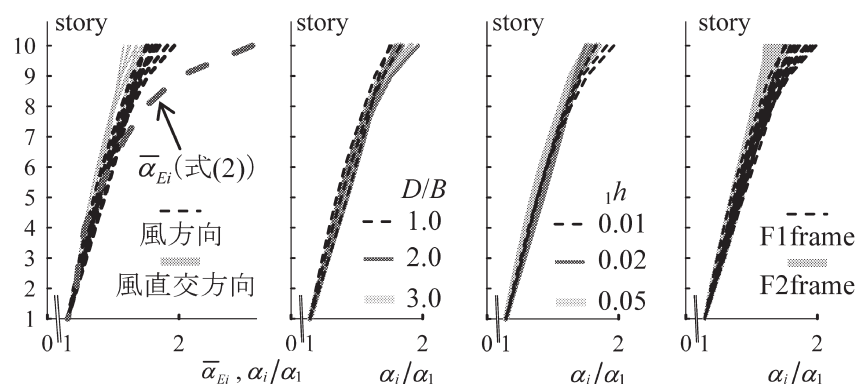

(a) 入力

(b) $D / B$

(c) ${ }_{1} h$

(d) frame

$$
\frac{\alpha_{i}}{\alpha_{1}}=\frac{Q_{i}}{\sum_{j=i}^{N} m_{j} \cdot g} / \frac{Q_{1}}{\sum_{j=1}^{N} m_{j} \cdot g}
$$

ここで， $Q_{i}$ : システムにおける $i$ 層の最大応答せん断力, $N$ : 層数, $m_{i}: i$ 層の質量, $g:$ 重力加速度を表す。

図 5(a) (d)に，弾性モデルにおける時刻歴風応答解析より得られ た $\alpha_{i} / \alpha_{1}$ (式(1)）を，解析パラメータ毎に示す。図 5(a)に, F1D1model における計 18 ケース (=風力入力方向 : 2 種類 ( 風方向風力, 風直 交方向風力 $) \times$ 辺長比 $D / B: 3$ 種類 $(1.0,2.0,3.0) \times$ 減衰定数 ${ }_{1} h$ : 3 種類 $(0.01,0.02,0.05))$ の結果を示す。秋山により提案された地 震応答を対象とした最適降伏せん断力係数分布 $\bar{\alpha}_{E i}\left(\right.$ 式 $\left.(2)^{11)}\right)$ を比較 のために図 5(a)に併記する（本論文では，風応答時との違いを示す ために，秋山による地震応答時の最適降伏せん断力係数分布 $\bar{\alpha}_{i}$ を $\bar{\alpha}_{E i}$ と表記する)。

$$
\begin{aligned}
& \bar{\alpha}_{E i}=1+1.5927 x_{i}^{\prime}-11.8519 x_{i}^{\prime 2}+42.5833 x_{i}^{\prime 3}-59.4827 x_{i}^{\prime 4}+30.1586 x_{i}^{\prime 5} \\
& x_{i}^{\prime}>2 \text { の場合 } \quad \text { (2a) } \\
& \bar{\alpha}_{E i}=1+0.5 x^{\prime} \\
& x_{i}^{\prime}<2 \text { の場合 } \quad(2 \mathrm{~b})
\end{aligned}
$$

ここで， $x_{i}^{\prime}$ は次式で表される ${ }^{11)}$

$$
\begin{array}{ll}
x_{i}^{\prime}=\frac{i-1}{N} & \text { 質量分布が均一の場合 } \\
x_{i}^{\prime}=1-\sum_{j=i}^{N} \frac{m_{j}}{M} & \text { 質量分布が不均一の場合 }
\end{array}
$$

ここに, $M$ : 総質量である。

図 5(a)より，風応答時の最大応答せん断力係数分布 $\alpha_{i} / \alpha_{1}$ (式(1)) と地震応答を対象とした最大応答せん断力係数分布 $\bar{\alpha}_{E i}$ (式(2)）を 比較すると，下層から中層にかけて $\alpha_{i} / \alpha_{1}$ は $\bar{\alpha}_{E i}$ と概致一致している が，上層では $\bar{\alpha}_{E i}$ より小さい結果となっていることが確認できる。こ れは，風応答は 1 次モードが支配的であり，地震時応答に比べて高 次モードの影響が小さいことが原因であると考えられる ${ }^{17)} 。 \alpha_{i} / \alpha_{1}$ を風方向風力之風直交方向風力で比較すると, 風方向風力の方が風 直交方向風力より上層において大きいことが確認できる。図 5(b)と (c)から，D/Bおよび ${ }_{1} h$ の差異による影響をそれぞれ確認する。ここ では, 風方向風力のみ計 9 ケース (=辺長比 $D / B: 3$ 種類 $(1.0,2.0$, $3.0) \times$ 減衰定数 ${ }_{1} h: 3$ 種類 $\left.(0.01,0.02,0.05)\right)$ の $\alpha_{i} / \alpha_{1}$ の結果を示 す。図 5(b)より， $\alpha_{i} / \alpha_{1}$ は上層で多少ばらつくが， $D / B$ の差異による 影響は小さいといえる。図 5(c)より， $\alpha_{i} / \alpha_{1}$ は ${ }_{1} h$ の差異による影響も 小さいことがわかった。なお，F1D1model（図 5(a)，(b)，(c)）で確 認できる傾向は, その他 3 つの model でも確認できた。図 5(d)には, 風方向風力における計 36 ケース (=辺長比 $D / B: 3$ 種類 $(1.0,2.0$, 
$3.0) \times$ 減衰定数 $h: 3$ 種類 $(0.01,0.02,0.05) \times$ model $: 4$ 種類 $($ F1D1, F1D2，F2D1，F2D2)）の結果を示寸。図 5(d)では，それぞれフレー ム剛性分布およびダンパー剛性分布の差異による影響を確認する。 図 5(d)より, フレーム剛性分布の差異による影響に着目すると, 剛 性分布の違いにより（図 3(a)), 上層において F1 frame の方が F2frame より， $\alpha_{i} / \alpha_{1}$ は多少大きいことが確認できる。

以上より，風応答時の弾性モデルにおける最大応答せん断力係数 分布 $\bar{\alpha}_{W i}$ は, 地震応答を対象とした最適降伏せん断力係数分布 $\bar{\alpha}_{E i}$ (式 (2)）と異なることが確認された。さらに， $\alpha_{i} / \alpha_{1}$ は風力および剛性分 布の差異による影響を受けることがわかった。

\section{4 風応答時の最適降伏せん断力係数分布の検証}

ダンパーの累積塑性ひずみエネルギー ${ }_{d} W_{p i}$ の分布を表すダンパー の累積損傷分布 $1 / d \gamma_{i}$ は, 時刻歴応答解析より得られるダンパーの累 積塑性変形倍率 ${ }_{d} \eta_{i}$ を用いて次式で表すことができる ${ }^{11}$ 。

$$
\frac{1}{{ }_{d} \gamma_{i}}=\frac{{ }_{d} W_{p i}}{\sum_{j=1}^{N}{ }_{d} W_{p j}}=\frac{{ }_{d} \eta_{i} \cdot{ }_{d} Q_{y i} \cdot{ }_{d} \delta_{y i}}{\sum_{j=1}^{N}{ }_{d} \eta_{j} \cdot{ }_{d} Q_{y j} \cdot{ }_{d} \delta_{y j}}
$$

ここで,

$$
{ }_{d} \eta_{i}=\frac{{ }_{d} W_{p i}}{{ }_{d} Q_{y i} \cdot{ }_{d} \delta_{y i}}
$$

ここに, ${ }_{d} Q_{y i}: i$ 層のダンパーの降伏せん断力, ${ }_{d} \delta_{y i}: i$ 層のダンパー の降伏変形を表す。

本論文では, 全層の ${ }_{d} \eta_{i}$ が一定となる $1 /{ }_{d} \gamma_{i}$ を基準状態 $1 /{ }_{d} \gamma_{0 i}$ と定 義する。基準状態の理論值 $1 /{ }_{d} \gamma_{0 i}$ は, 式(4)において ${ }_{d} \eta_{i}={ }_{d} \eta$ を代入す ることで次式のように表され（付録 $\mathrm{A}$ )，応答值に依存しないダンパ 一の特性值 $\left({ }_{d} Q_{y i},{ }_{d} k_{i}\right.$ または $\left.{ }_{d} \delta_{y i}\right)$ のみで基準状態の理論值 $1 / d_{d} \gamma_{0 i}$ を 決定することができる。

$$
\frac{1}{{ }_{d} \gamma_{0 i}}=\frac{{ }_{d} Q_{y 0 i} \cdot{ }_{d} \delta_{y i}}{\sum_{j=1}^{N}{ }_{d} Q_{y 0 j} \cdot{ }_{d} \delta_{y j}}=\frac{{ }_{d} Q_{y 0 i}^{2} /{ }_{d} k_{i}}{\sum_{j=1}^{N}{ }_{d} Q_{y 0 j}^{2} /{ }_{d} k_{j}}
$$
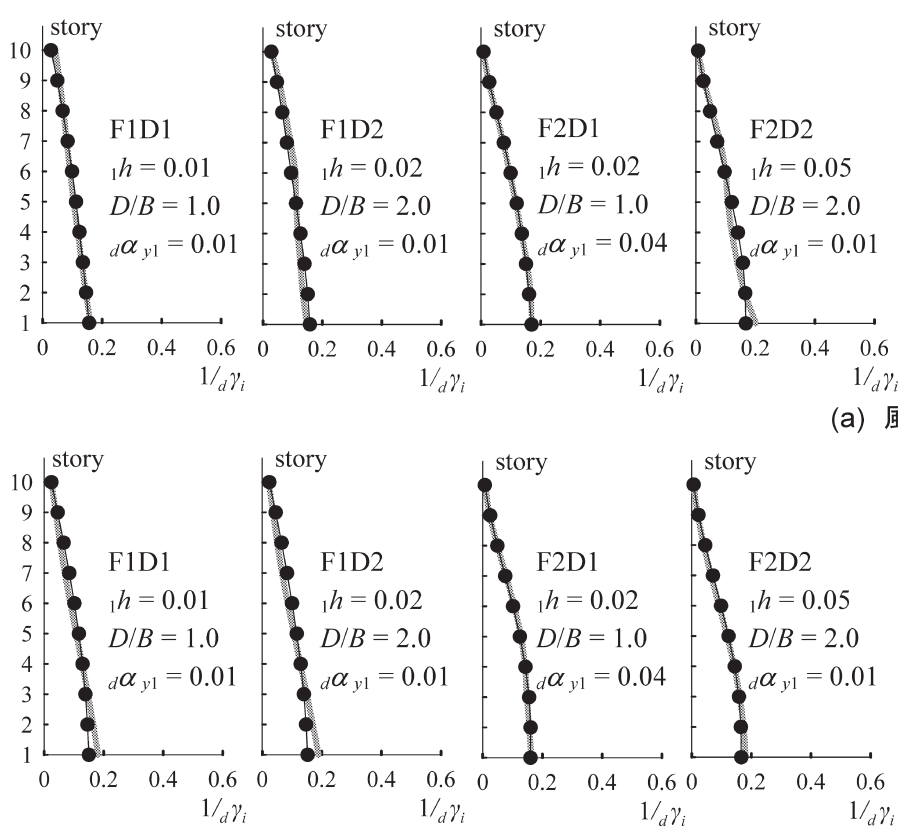
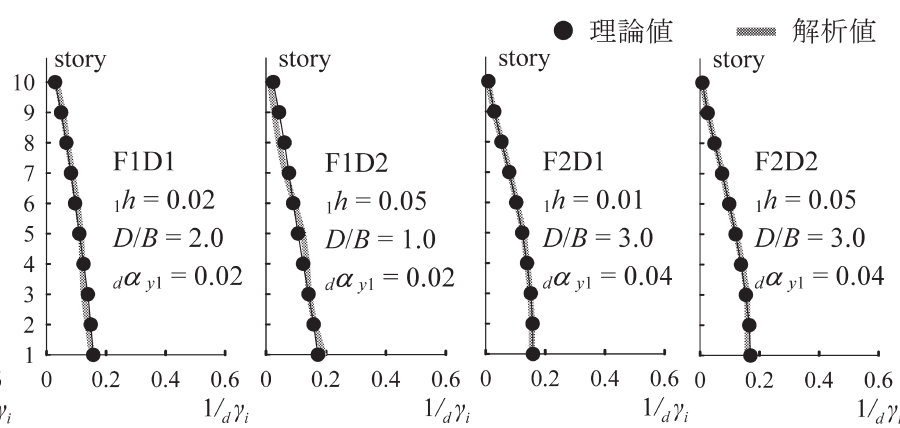

(a) 風方向

${ }_{d} Q_{y 0 i}$ は基準状態を満足するためのダンパーの最適降伏せん断力 であり，式(7)より算出できる（付録 $\mathrm{B}$ )。

$$
{ }_{d} Q_{y 0 i}={ }_{d} \alpha_{y 1} \cdot \overline{\alpha_{i}} \cdot\left(\frac{{ }_{d} k_{i}}{k_{i}}\right) /\left(\frac{d k_{1}}{k_{1}}\right) \cdot \sum_{j=i}^{N} m_{j} \cdot g
$$

ここで, ${ }_{d} k_{i}: i$ 層におけるダンパー剛性， $k_{i}: i$ 層におけるシステ ムの弾性剛性, ${ }_{d} \alpha_{y 1}$ : 第 1 層のダンパー降伏せん断力係数（＝第 1 層のダンパーの降伏せん断力 / 全重量) であり, 本論文では ${ }_{d} \alpha_{y 1}$ を ダンパー量, 式(7)の ${ }_{d} Q_{y 0 i}$ を用いて決定したダンパーの降伏せん断力 分布 ${ }_{d} Q_{y 0 i} I_{d} Q_{y 01}$ をダンパーの最適分布と呼ぶこととする。 $\bar{\alpha}_{i}$ は基準 状態を満足するためのシステムの最大応答せん断力係数分布であり, 最適降伏せん断力係数分布と呼ばれる ${ }^{11)}$ (本論文では, 地震応答時 の最適降伏せん断力係数分布 $\bar{\alpha}_{i}$ を $\bar{\alpha}_{E i}$ と表記し(前述), 風応答時の 最適降伏せん断力係数分布 $\bar{\alpha}_{W i}$ と表記する)。

弾性モデルの時刻歴風応答解析より求められた最大応答せん断力 係数分布 $\alpha_{i} / \alpha_{1}$ を式(7)の $\bar{\alpha}_{i}$ に代入してダンパーの降伏せん断力 ${ }_{d} Q_{y 0 i}$ を設定し, 弾塑性時刻歴風応答解析の結果を用いて式(4)より ダンパーの累積損傷分布 $1 / d \gamma_{i}$ を算出する。その結果と基準状態の理 論值 $1 / d \gamma_{0 i}$ （式(7)）の比較を行なうことで，弹性モデルの最大応答 せん断力係数分布 $\alpha_{i} / \alpha_{1}$ (式(1)）を，風応答時における最適せん断力 係数分布 $\bar{\alpha}_{W i}$ として用いることができるかを確認する。

図 6(a), (b)に，風方向および風直交方向風力を入力した際の弾塑性 時刻歴風応答解析結果を用いて式(4)より算出したダンパーの累積損 傷分布 $1 / d \gamma$ （解析值）と, 式(6)より求めた基準状態 $1 / d \gamma_{0 i}$ （理論值） の比較をそれぞれ示寸。なお，図 6 には計 216 ケース（=風力入力 方向 : 2 種類 ( 風方向風力, 風直交方向風力 ) $\times$ 辺長比 $D / B: 3$ 種 類 $(1.0,2.0,3.0) \times$ 減衰定数 $1 h: 3$ 種類 $(0.01,0.02,0.05) \times$ model : 4 種類 $($ F1D1，F1D2，F2D1，F2D2 $) \times{ }_{d} \alpha_{y 1}: 3$ 種類 $(0.01,0.02$, $0.04)$ ）の中から，典型的な解析結果を例として示している。図 6 上 り，風力入力方向， $D / B,{ }_{1} h$, フレームの剛性分布やダンパー剛性分 布, さらに ${ }_{d} \alpha_{y 1}$ によらず，いずれのケースにおいても，式(7)のダン

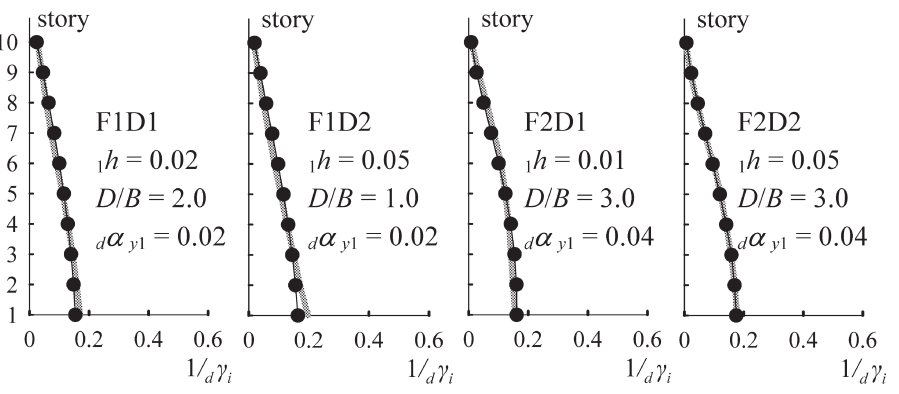

(b) 風直交方向

図 6 最適分布におけるダンパーの累積損傷分布の理論值と弾塑性風応答解析結果の比較 
パー降伏せん断力 ${ }_{d} Q_{y 0 i}$ を用いた弾塑性時刻歴風応答解析より得ら れたダンパーの累積損傷分布 $1 /{ }_{d} \gamma_{i}$ は, 全層において基準状態 $1 / d \gamma_{0 i}$ の理論值（式(6)）と精度よく一致していることが確認できる。

以上より, 弾性モデルにおける風応答時の最大応答せん断力係数 分布 $\alpha_{i} / \alpha_{1}$ を, 風応答時における基準状態を満足する最適降伏せん断 力係数分布 $\bar{\alpha}_{W i}$ として用いることができることがわかった。

\section{3. 風応答時における最適降伏せん断力係数分布の予測手法}

\section{1 スペクトルモーダル解析を用いた予測手法}

前章では弾性モデルの時刻歴風応答解析結果より得られた最大応 答せん断力係数分布 $\alpha_{i} / \alpha_{1}$ を, 風応答時における最適降伏せん断力係 数分布 $\bar{\alpha}_{W i}$ として用いることができることを示した。本章では, 筆者 らの提案した手法 ${ }^{17)}$ を準用して, 時刻歴風応答解析を行なうことな く, 風応答時におけるダンパーの最適降伏せん断力係数分布 $\bar{\alpha}_{W i}$ を予 測する手法を示す。

$i$ 層の風力時刻歴 $F_{i}(t)$ と弾性モデルにおける 1 次振動モード ${ }_{1} \phi_{i}$ を用いて 1 次モーダル風力時刻歴 $1 F(t)$ は次式より算出される。

$$
{ }_{1} F(t)=\sum_{i=1}^{N}{ }_{1} \phi_{i} \cdot F_{i}(t)
$$

変動成分の風外力に対して弾塑性風応答を評価する場合は, 共振

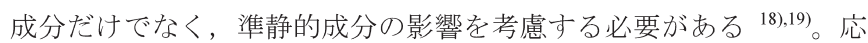
答のパワースペクトル密度は, 境界振動数 $f$ Bound を境に準静的成分 （添字 $B$ で表す）と共振成分（添字 $R$ で表す）に分離することがで きる ${ }^{18), 20)}$ 。本論文でも文献 18) と同様に, 弾性モデルの 1 次固有振動 数 ${ }_{1} f$ の $1 / 3$ を境界振動数 $f_{\text {Bound }}$ とする。

1 次モーダル風力のパワースペクトル密度 ${ }_{1} S_{F}(f)$ と, 弾性モデルの 1 次モーダル剛性 ${ }_{1} K$ および 1 次の減衰定数, $h$ を用いてスペクトルモ 一ダル解析により，1 次モーダル応答変位 19 の共振成分の標準偏差 ${ }_{1} \sigma_{R q}$ を算出する (式(9))。

$$
\begin{aligned}
& { }_{1} \sigma_{R q}=\left[\int_{f_{\text {Bound }}}^{\infty}\left|{ }_{1} H(f)\right|^{2} \cdot{ }_{1} S_{F}(f) d f\right]^{1 / 2} \\
& { }_{1} H(f)=\frac{1}{1-\left(\frac{f}{{ }_{1} f}\right)^{2}+2 i_{1} h \frac{f}{{ }_{1} f}} \cdot \frac{1}{{ }_{1} K}
\end{aligned}
$$

ここで, ${ }_{1} H(f)$ : 弾性モデルにおける 1 次の周波数応答関数, $i:$ 虚 数単位を表す。

層間変位の準静的成分は, 外乱との静的な力の釣合から算出でき る。まず, 式(11)より, 風外力の準静的成分によって $i$ 層に作用する せん断力の準静的成分の標準偏差 $\sigma_{B} Q_{i}$ を算出する。

$$
\sigma_{B Q_{i}}=\sum_{j=i}^{N} \sigma_{B F_{j}}=\sum_{j=i}^{N}\left[\int_{0}^{f_{B o u n d}} S_{F j}(f) d f\right]^{1 / 2}
$$

ここで， $\sigma_{B F_{j}}: i$ 層における風力の準静的成分の標準偏差, $S_{F i}(f)$ : $i$ 層における風力のパワースペクトル密度を表す。

次に, 算出した $\sigma_{B} Q_{i}$ を用いて, 式(12)より $i$ 層における層間変位 の準静的成分の標準偏差 $\sigma_{B} \delta_{i}$ を求める。

$$
\sigma_{B \delta_{i}}=\frac{\sigma_{B Q_{i}}}{k_{i}}=\frac{\sigma_{B Q_{i}}}{{ }_{f} k_{i}+{ }_{d} k_{i}}
$$

風応答時における多質点系での弾性モデルの層間変位の標準偏差 $\sigma_{\delta_{i}}$ は, 次式のように 1 次共振成分と準静的成分より近似的に求め ることができる ${ }^{17)}$

$$
\sigma_{\delta_{i}}=\left[\left\{{ }_{1} \sigma_{R q} \cdot\left({ }_{1} \phi_{i}-{ }_{1} \phi_{i-1}\right)\right\}^{2}+\sigma^{2}{ }_{B \delta_{i}}\right]^{1 / 2}
$$

式(13)より求めた $\sigma_{\delta_{i}}$ を用いて, 次式から弾性モデルにおける $i$ 層の 最大層間変位 $\delta_{i}$ を算出する。

$$
\delta_{i}=\sigma_{\delta_{i}} \cdot g_{p}
$$

ここで, $g_{p}$ : ピークファクターであり, 次式より求める ${ }^{15)}$

$$
g_{p}=\sqrt{2 \ln \left(600_{1} f\right)+1.2}
$$

ここに, ${ }_{1} f$ : システム弾性 1 次固有振動数である。

弾性モデルにおける $i$ 層の最大応答せん断力 $Q_{i}$ を, 式(14)の $\delta_{i}$ と システムの弾性剛性 $k_{i}$ を用いて次式より求めることができる。

$$
Q_{i}=k_{i} \cdot \delta_{i}
$$

最終的に，式(16)より算出した $Q_{i}$ を式(1)に代入することで最大応答 せん断力係数分布 $\alpha_{i} / \alpha_{1}$, つまり最適降伏せん断力係数分布 $\bar{\alpha}_{W i}$ を, 時刻歷風応答解析を用いることなく予測することができる。

\section{2 風応答時の最適降伏せん断力係数分布の予測値の検証}

図 7 に, 2.3 節で述べた弾性モデルにおける時刻歴風応答解析より 求めた $\alpha_{i} / \alpha_{1}$ （解析值）と，3.1 節で述ベたスペクトルモーダル解析 より求めた $\bar{\alpha}_{W i}$ (予測值) の比較を示す。なお, 図 7 には, 計 72 ケ 一ス (=風力入力方向 : 2 種類 (風方向風力, 風直交方向風力) $\times$ 辺 長比 $D / B: 3$ 種類 $(1.0,2.0,3.0) \times$ 減衰定数 ${ }_{1} h: 3$ 種類 $(0.01,0.02$, $0.05) \times$ model : 4 種類 (F1D1, F1D2, F2D1, F2D2)) の中から, 典 型的な解析結果を示している。図 7 より, 風力入力方向, model, 減 衰定数 ${ }_{1} h$ および辺長比 $D / B$ の差異に関係なく, 全てのケースにおい て, スペクトルモーダル解析より予測した $\bar{\alpha}_{W i}$ (予測值) は弾性モデ ルにおける時刻歴風応答解析より求めた $\alpha_{i} / \alpha_{1}$ （解析值）と精度良く 一致していることが確認できる。

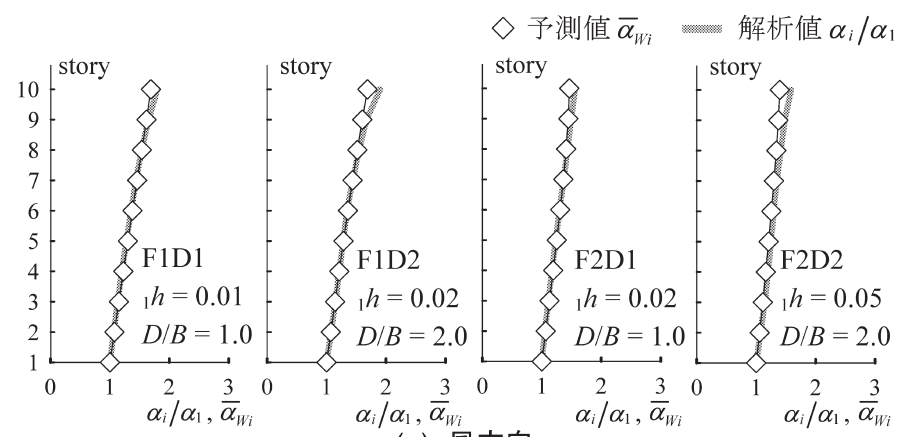

(a) 風方向

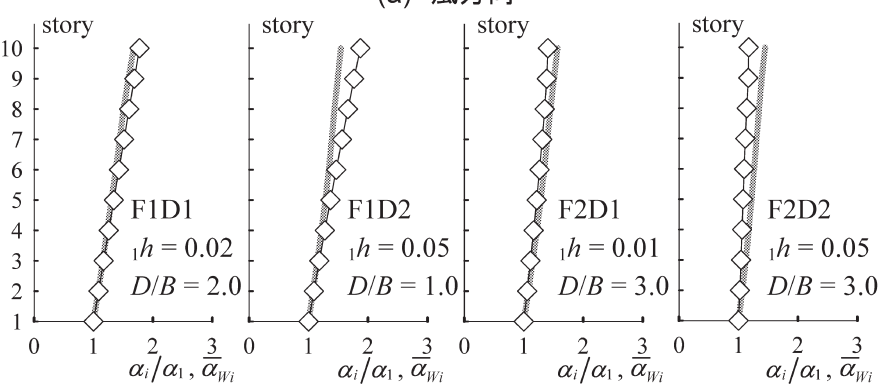

(b) 風直交方向

図 7 風応答時の最適せん断力係数分布の予測値と 弾性モデルによる時刻歴風応答解析結果の比較 

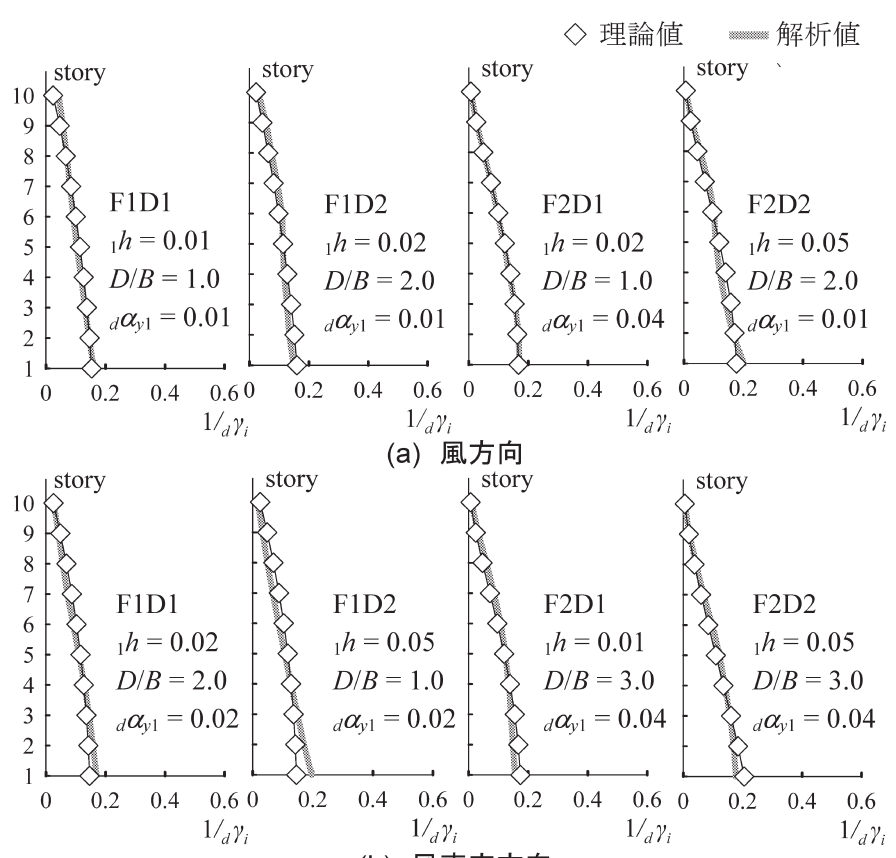

(b) 風直交方向

図 8 風応答時の最適せん断力係数分布の予測値を用いた 弾塑性風応答解析結果と理論值の比較 (最適分布)

次に, $\bar{\alpha}_{W i}$ (予測值) を用いて, 式(7)よりダンパーの最適降伏せ 几断力 ${ }_{d} Q_{y 0 i}$ を設定し, 弾塑性時刻歴風応答解析を行って得られる夕゙ ンパーの累積損傷分布 $1 d_{d} \gamma_{i}$ が基準状態 $1 /{ }_{d} \gamma_{0 i}$ の理論値（式(6)）を満 足するか確認する。図 8 に, ダンパーの最適降伏せん断力 ${ }_{d} Q_{y 0 i}$ を設 定した弾塑性風応答解析より求めたダンパーの累積損傷分布 $1 / d_{d} \gamma_{i}$ と, 基淮状態 $1 / d \gamma_{0 i}$ の理論值（式(6)）の比較を示す。計 216 ケース（= 風力入力方向 : 2 種類 (風方向風力, 風直交方向風力) $\times$ 辺長比 $D / B: 3$ 種類 $(1.0,2.0,3.0) \times$ 減衰定数 $1 h: 3$ 種類 $(0.01,0.02,0.05)$ $\times$ model : 4 種類 $($ F1D1, F1D2, F2D1, F2D2 $) \times{ }_{d} \alpha_{y 1}: 3$ 種類 $(0.01$, $0.02 ， 0.04) ）$ について検討を行なっているが，ここでは典型的な解 析結果を示している。図 8 より, $\bar{\alpha}_{W i}$ の予測值を用いて式(7)よりダ ンパーの最適降伏せん断力 $d Q_{y 0 i}$ を設定した弾塑性時刻歴風応答解 析結果より得られた $1 / d \gamma_{i}$ は, 基準状態 $1 /{ }_{d} \gamma_{0 i}$ の理論值に精度よく一 致していることが確認できる。なお, 風力, 辺長比 $D / B$, 減衰定数 ${ }_{1} h$, model および ${ }_{d} \alpha_{y 1}$ に関係なく, 全解析ケースについても同様の 高い精度であることを確認しており, 詳細については付録 $\mathrm{C}$ を参照 されたい。

以上より, 準静的成分の影響を考慮したスペクトルモーダル解析 を用いることで, 時刻歴応答解析を行なうことなく風応答時におけ るダンパーの最適降伏せん断力係数分布 $\bar{\alpha}_{W i}$ を予測する本手法の妥 当性が確認できた。

\section{4. 風応答時における累積損傷分布の予測手法 \\ 4.1 累積損傷分布の予測式}

前章までは, 風応答時の最適降伏せん断力係数分布 $\bar{\alpha}_{W i}$ からダンパ 一の最適降伏せん断力 ${ }_{d} Q_{y 0 i}$ を設定した最適分布 ${ }_{d} Q_{y 0 i} / d Q_{y 01}$ を用いて いた。しかし, 現実的には, 任意の降伏せん断力分布に対するダン

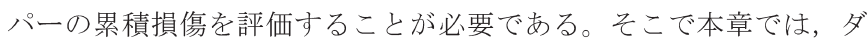
ンパーの降伏せん断力分布が最適分布と異なる場合におけるダンパ
一の累積損傷分布の予測手法について述べる。 ダンパーの累積塑性ひずみエネルギー ${ }_{d} W_{p}$ の分布を表すダンパー の累積損傷分布 $1 / d \gamma_{i}$ の予測值は，式(17)より求められる ${ }^{21,22)}$

$$
\begin{aligned}
& \frac{1}{{ }_{d} \gamma_{i}}=\frac{{ }_{d} W_{p i}}{\sum_{j=1}^{N}{ }_{d} W_{p j}}=\frac{{ }_{d} S_{i} \cdot d p_{i}^{-d n_{i}}}{\sum_{j=1}^{N}{ }_{d} S_{j} \cdot d{ } p_{j}^{-d n_{j}}} \\
& \text { ここで,} \\
& { }_{d} S_{i}=\left(\sum_{j=i}^{N} \frac{m_{j}}{M}\right)^{2} \cdot{ }_{d} \bar{\alpha}_{i}^{2} \cdot \frac{{ }_{d} k_{1}}{{ }_{d} k_{i}}, \quad{ }_{d} p_{i}=\frac{{ }_{d} \alpha_{y i}}{{ }_{d} \alpha_{y 1}} \cdot \frac{1}{{ }_{d} \bar{\alpha}_{i}}
\end{aligned}
$$

ここに, ${ }_{d} p_{i}: i$ 層ダンパーの強度低下率, ${ }_{d} n_{i}: i$ 層の損傷集中指数 $(4.2$ 節後述), ${ }_{d} \bar{\alpha}_{i}: i$ 層ダンパーの最適降伏せん断力係数分布を表し, 次 式より算出できる ${ }^{21), 22)}$ 。

$$
{ }_{d} \bar{\alpha}_{i}=\bar{\alpha}_{i}\left(\frac{{ }_{d} k_{i}}{k_{i}}\right) /\left(\frac{{ }_{d} k_{1}}{k_{1}}\right)
$$

式(17)は, 秋山による累積損傷分布の提案式 ${ }^{11)}$ をレレムとダンパー の剛性比が各層で異なる場合にも適用できるように拡張したもので あり，剛性比が各層で等しい場合，式(17)は秋山による累積損傷分布 の提案式と一致する $\left.{ }^{21}\right)_{0}$ 。なお, ダンパーの降伏せん断力係数分布 ${ }_{d} \alpha_{y}$ ${ }_{d} \alpha_{y 1}$ がダンパーの最適降伏せん断力係数分布 ${ }_{d} \bar{\alpha}_{i}$ に一致する時，す なわち ${ }_{d} p_{i}=1$ となる場合は, 式(17)は基準状態 $1 / d \gamma_{0 i}$ の理論值 (式(6)) と一致する (付録 A)。

\section{2 風応答時における損傷集中指数の検討}

式(17)中の損傷集中指数 ${ }_{d} n_{i}$ は, ダンパーの最適せん断力係数分布 ${ }_{d} \bar{\alpha}_{i}$ からの偏りを表す強度低下率 ${ }_{d} p_{i}$ の指数であり, ダンパーの累積 損傷分布 $1 / d \gamma_{i}$ 老補正する值である。 $d n_{i}$ が大きいほど弱い層への損 傷が集中する割合が大きくなることを意味する。地震応答時の損傷 集中指数 $n_{s}$ が北村ら ${ }^{12}$ により次式で提案されている（本論文では, 風応答時との違いを示すために, 北村らによる地震応答時の $n_{s}{ }^{12)}$ ${ }_{d} n_{E i}$ と表記し, 後述する風応答時の損傷集中指数を ${ }_{d} n_{W i}$ と表記する)。

$$
\begin{array}{ll}
{ }_{d} n_{E i}=12 & r_{q i} \leq 0.33 \\
{ }_{d} n_{E i}=-2+8 \cdot r_{q i}{ }^{-0.5} & 0.33<r_{q i} \leq 7.0 \\
{ }_{d} n_{E i}=1 & r_{q i}>7.0
\end{array}
$$

上限值の 12 は柱降伏型のラーメン構造に対して用いる值 ${ }^{11)}$ であり, 下限值の 1 は損傷集中が無視できる場合の值である ${ }^{12)}$ 。 $r_{q i}$ はフレー ムとダンパーのせん断力の分担率を表す (式(21))。

$$
r_{q i}=\frac{{ }_{f} Q_{i}}{{ }_{d} Q_{y i}}=\frac{{ }_{f} k_{i} \cdot \delta_{i}}{{ }_{d} k_{i} \cdot{ }_{d} \delta_{y i}}
$$

地震応答と風応答では損傷集中が異なることが予想されるが，風 応答時における損傷集中指数 ${ }_{d} n_{W i}$ については検討されていない。本 節では，文献 11),12)と同様の手法を用いて風応答時における損傷集 中指数 ${ }_{d} n_{W i}$ を求め, それをモデル化する。

まず，ダンパーの降伏せん断力分布を設定し，時刻歷風応答解析 を行ない，全層のダンパーで吸収したエネルギー $\Sigma_{d} W_{p}$ に対する $i$ 層 ダンパーで吸収したエネルギー ${ }_{d} W_{p i}$ の分担率 $\left({ }_{d} W_{p i} / \Sigma_{d} W_{p}\right)$ を算出し, この值を $a_{i}$ とする。この時, ダンパーの降伏せん断力分布は自由に 設定してよい。次に，ダンパー剛性は変化させず， $i$ 層のダンパー の降伏せん断力のみを ${ }_{d} p_{i}$ 倍（ ${ }_{d} p_{i}<1 ）$ させて損傷集中層（弱層）を 設けたモデルを作成する。そのモデルを用いて時刻歴風応答解析を 
表 2 解析パラメータ

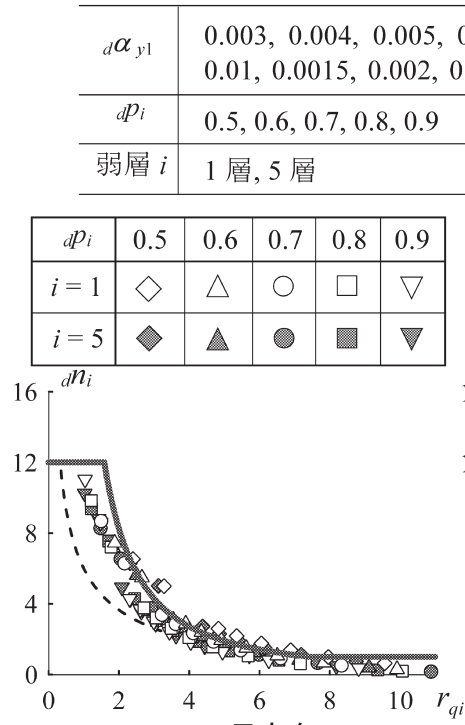

(a) 風方向

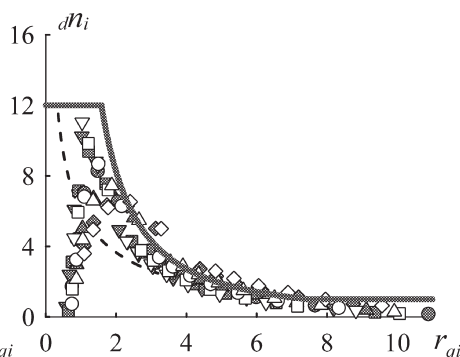

(b) 風直交方向

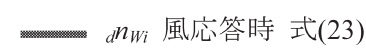

- - - ${ }_{d} n_{E i}$ 地震応答時 式 $(20)^{12)}$

図 $9 n_{s}-r_{q}$ 関係

行ない $i$ 層ダンパーのエネルギー分担率 $\left({ }_{d} W_{p i} / \Sigma_{d} W_{p}\right)$ を算出し, こ の值を $b_{i}$ とする。以上のようにして求めた $a_{i}$ と $b_{i}$ を用いて, 式(22 $)^{11}$ により風応答時における損傷集中指数 ${ }_{d} n_{W i}$ を求める。

$$
{ }_{d} n_{W i}=\frac{-\ln \frac{b_{i}\left(1-a_{i}\right)}{a_{i}\left(1-b_{i}\right)}}{\ln _{d} p_{i}}
$$

本節での検討には F1D1model, $D / B=1.0$, 減衰定数は ${ }_{1} h=0.02$, ダンパーの降伏せん断力分布は最適分布を用いる。解析パラメータ は風力 (風方向, 風直交方向), ダンパーの第 1 層の降伏せん断力係 数 ${ }_{d} \alpha_{y 1}$, 損傷集中層（弱層）とその層のダンパーの降伏せん断力の 低減係数 $p_{d}$ である（表 2)。図 9(a)，(b)に風方向および風直交方向 風力入力時における, 式(22)より求めた損傷集中指数 ${ }_{d} n_{W i}$ (プロット) とフレームとダンパーの負担せん断力 $r_{q i}$ との関係を示す。ここでは, 全ての解析結果を精査し, 累積損傷を評価する上で問題とならない ダンパーの塑性化の小さい範囲（付録 D 参照）の結果は, 図 9 から 除いている。図 9 より, 風応答時の損傷集中指数 ${ }_{d} n_{W i}$ (プロット) は, $1.0<r_{q}<6.0$ において地震応答時の損傷集中指数 ${ }_{d} n_{E i}$ の提案式 （式(20)：破線）を上回っていることが確認できる。これは, 地震 応答の場合, 高次振動モードの影響により, 弱層以外の層にも損傷 エネルギーが分散すると考えられるが, 風応答時は, 地震応答に比 べて 1 次振動モードが支配的となるため ${ }^{17), 23)}$, 特定層への損傷集中 が地震応答よりも大きくなったためと考えられる。加えて, 風応答 と地震応答における塑性変形振幅と塑性化回数の違いも影響してい ると思われる。図9(a), (b)を比較すると, 風方向に比べて風直交方 向の方が大きな值を示していることが確認できる。これも, 風方向 に比べて風直交方向の方が 1 次モードの影響が大きいため ${ }^{177}$ である と考えられる。しかし, 累積損傷分布を予測する際, 損傷集中指数 は風力の種類に因らず統一的に表現されている方が便利である。そ こで本論文では, 損傷集中が安全側に評価されるように, 風方向風 力入力時よりも ${ }_{d} n_{W i}$ が大きい風直交方向風力入力時を対象に ${ }_{d} n_{W i}$ を モデル化することとした。文献 24$)$ を参考に,$p_{d}=0.8$ のときに最大
となる值を用いて，風応答時における損傷収集指数 ${ }_{d} n_{W i}$ を最小二乗 法により式(23)でモデル化した。なお，式(20)と同様に ${ }_{d} n_{W i}$ の上限值 を12，下限値を 1 とした。

$$
\begin{array}{ll}
n_{W s i}=12 & r_{q i} \leq 1.6 \\
n_{W s i}=25 \cdot r_{q i}{ }^{-1.6} & 1.6<r_{q i} \leq 7.5 \\
n_{W s i}=1 & r_{q i}>7.5
\end{array}
$$

\section{3 予測精度の検証}

本節では，弾塑性時刻歴風応答解析 より求めたダンパーの累積損傷分布 $1 / d \gamma_{i}$ と, 式(23)から算出した ${ }_{d} n_{W i}$ を用 いて, 式(17)より求めた $1 / d \gamma_{i}$ の予測値 を比較することで，風応答時における ダンパーの累積損傷分布の予測手法の 精度と適用範囲を検討する。

本節で用いるダンパーの降伏せん断 力分布 ${ }_{d} Q_{y i} /_{d} Q_{y 1}$ は, 最適分布をもと に，3つのグループに分割（圆 印 $1 \sim 3$ 層， $4 \sim 7$ 層， 8 10 層）した 3 段階分

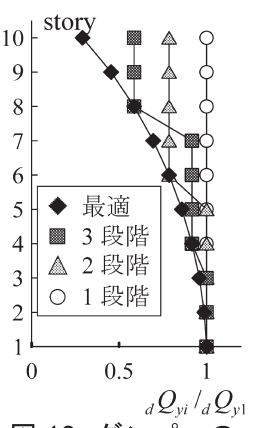

図 10 ダンパーの

降伏せん断力分布
布，2つのグループに分割（ $\Delta$ 印 $1 \sim 5$ 層， 6 10 層）した 2 段階分 布, および 1 つ統一した 1 段階分布（（印）の3 種類を用いる（図 10)。

図 11(a)，(b)に，風方向および風直交方向入力時における弾塑性時 刻歷風応答解析より得られたダンパーの累積損傷分布 $1 / d \gamma_{i}$ と予測值 の比較を示す。ここでは，式(23)の妥当性および式(17)による予測精 度の検証が主目的であるため, 式(23)中の $r_{q i}$ を算出する際に用いる フレームの最大応答せん断力 ${ }_{f} Q_{i}$ には, 弾塑性時刻歴風応答解析の結 果を用いている。検討は計 648 ケース (=風力入力方向 : 2 種類 ( 風 方向風力, 風直交方向風力 $) \times$ 辺長比 $D / B: 3$ 種類 $(1.0,2.0,3.0) \times$ 減衰定数 $1 h: 3$ 種類 $(0.01,0.02,0.05) \times$ model : 4 種類 (F1D1, F1D2, $\mathrm{F} 2 \mathrm{D} 1, \mathrm{~F} 2 \mathrm{D} 2) \times$ ダンパーの降伏せん断力分布 ${ }_{d} Q_{y i} /_{d} Q_{y 1}: 3$ 種類 $(3$ 段階分布, 2 段階分布, 1 段階分布 $) \times{ }_{d} \alpha_{y 1}: 3$ 種類 $\left.(0.01,0.02,0.04)\right)$ で行なっている。図 11 には，パラメータが予測精度に及ぼす影響を 確認できるように，広い範囲でかつ典型的な解析結果を選んで示し ている。ここで, ダンパーの塑性化の程度を評価する指標として, 入力エネルギー $E$ に占める全層におけるダンパーの累積塑性ひずみ エネルギー $\Sigma_{d} W_{p i}$ の割合をダンパーのエネルギー分担率 $\alpha_{p}$ として式 (24)で定義する。

$$
\alpha_{p}=\sum_{i=1}^{N}{ }_{d} W_{p i} / E
$$

ここで,

$$
E=\int_{0}^{t_{0}} \sum_{i=1}^{N} \dot{x}_{i}(t) F_{i}(t) d t
$$

ここに， $t_{0}$ ：評価時間 $(600 \mathrm{~s}), \quad \dot{x}_{i}(t): i$ 層の応答速度である。

式(17)の累積損傷分布 $1 / d \gamma_{i}$ は，全層で值を合算すると 1 となるも のである。そこで本論文では，累積損傷分布の予測精度を評価する 指標として，1/d $\gamma_{i}$ の予測値 $\left[1 / d \gamma_{i}\right]_{p}$ と時刻歷解析結果 $\left[1 /{ }_{d} \gamma_{i}\right]_{c}$ の差の 絶対值の平均值を予測誤差 $R_{1 / d \gamma_{i}}$ と呼び，式(26)で定義する。

$$
R_{1 / d \gamma_{i}}=\sum_{i=1}^{N}\left|\left[1 /{ }_{d} \gamma_{i}\right]_{p}-\left[1 /{ }_{d} \gamma_{i}\right]_{c}\right| / N
$$




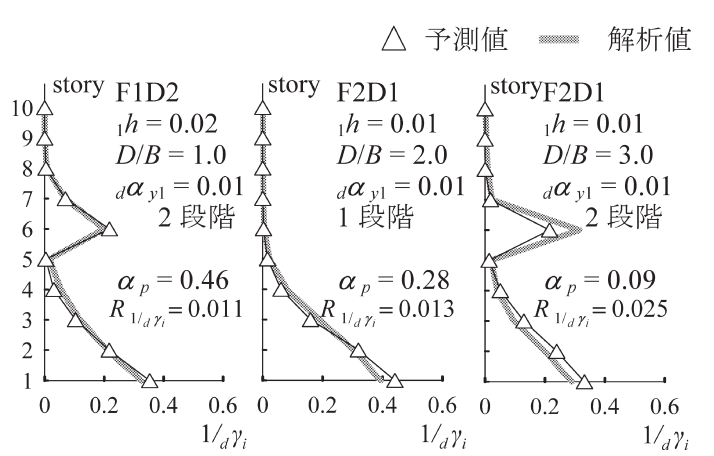

(a) 風方向

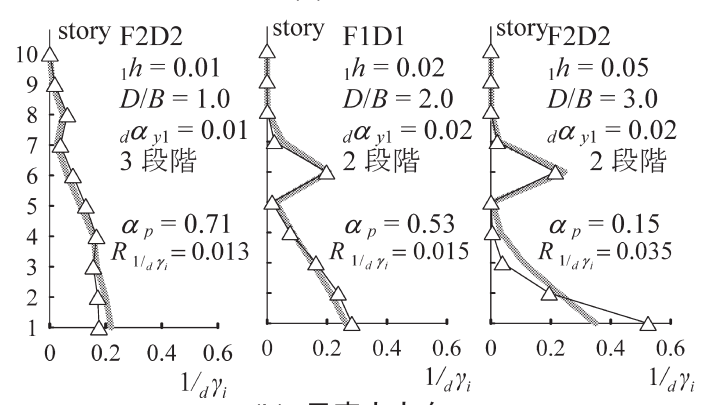

(b) 風直交方向

図 11 風応答時の損傷集中指数 ${ }_{a} n_{W i}$ を用いた ダンパーの累積損傷分布の予測值と弾塑性時刻歴解析結果の比較

はじめに, 図 11 の弾塑性時刻歴風応答解析結果に着目する。ダン パーの降伏せん断力分布を最適分布とした場合（図 8) と比較して, 図 11 の結果は下層部ダンパーの累積損傷が大きいことが確認できる。 これは, 図 10 からもわかるように, 図 11 で用いている 1 3 段階分 布は, 最適分布に比べて上層のダンパー降伏せん断力が高く, 相対 的に降伏せん断力の低い下層部のダンパーにエネルギーが集中した ためである。また， 2 段階や 3 段階分布では，ダンパーの降伏せん断 力分布が不連続となる層にエネルギーが集中していることも確認で きる。これは，その層におけるダンパーの降伏せん断力が直下の層 に比べて小さいため，相対的に弱層となるためである。

次に, 予測值と時刻歴解析結果の比較を行なう。式(23)より求めた ${ }_{d} n_{W i}$ を用いて式(17)より算出される $1 /{ }_{d} \gamma_{i}$ の予測值は, $\alpha_{p}=0.01$ とな る場合を除いて，上述したような最適分布とことなる場合の $1 / d_{d} \gamma_{i}$ の 特徵を良く再現しており, かつ $1 / d \gamma_{i}$ の值も精度よく一致しているこ とが図 11 より確認できる。さらに，予測誤差 $R_{1 / d \gamma_{i}}$ は，ダンパーの エネルギー分担率 $\alpha_{p}$ が大きいほど小さな值となっていることがわか る。一方, $\alpha_{p}=0.01$ となる場合において, 予測值は, 弾塑性時刻歴 風応答解析結果と大きく異なる分布となっていることが確認できる。

最後に, 予測誤差 $R_{1 / d} \gamma_{i}$ を全てのケースで検証する。図 12 に, 縦 軸を予測誤差 $R_{1 / d} \gamma_{i}$, 横軸をダンパーのエネルギー分担率が $\alpha_{p}$ とし, 計 648 ケースの結果を示す。図 12(a)には, 風力入力方向および ${ }_{d} \alpha_{y 1}$ を, 図 12(b)には, model およびダンパーの降伏せん断力分布 ${ }_{d} Q_{y i} /_{d} Q$ ${ }_{y 1}$ を凡例にして図示している。図 12(a)より, 風方向風力と風直交方 向風力入力時で $R_{1 / d \gamma_{i}}$ の大きな違いは確認されず, 本予測手法の予測 精度が風力の違いによる影響を受けにくいことがわかる。図 12(b)よ り, model やダンパーの降伏世ん断力分布 ${ }_{d} Q_{y i} l_{d} Q_{y 1}$ の違いについて も，図 12(a)と同様に， $R_{1 / d y_{i}}$ に大きな差異は確認できない。紙幅の 都合上図示していないが， $D / B$ および ${ }_{1} h$ の違いが予測精度に与える 影響も小さいことを確認している。

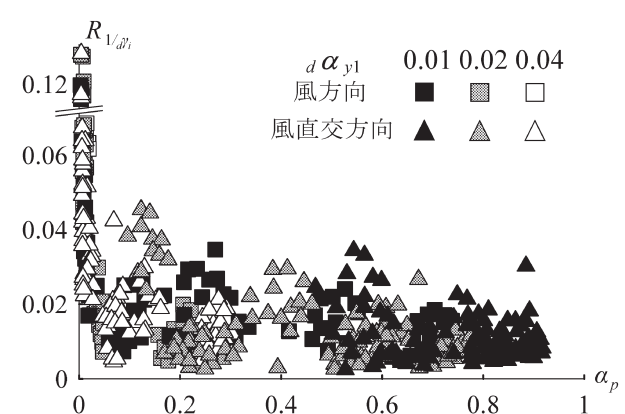

(a) 風力入力方向およびダンパー量による影響

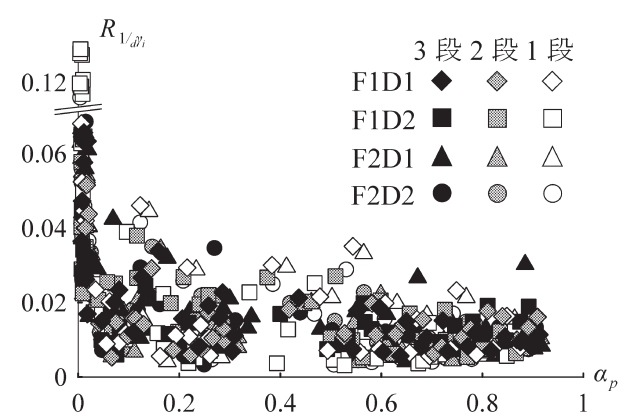

(b) model および ${ }_{d} Q_{y i} I_{d} Q_{y 1}$ による影響

\section{図 12 ダンパーの損傷分布の予測値と時刻歴結果との平均誤差}

図 12 より, ダンパーのエネルギー分担率 $\alpha_{p}$ が増加するほど予測 誤差 $R_{1 / d y_{i}}$ は減少していることが確認でき, 本予測手法は $\alpha_{p}$ が増加 するほど精度が高いといえる。一方で, ダンパーのエネルギー吸収

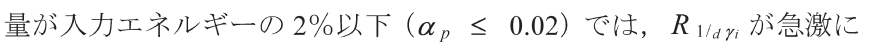
大きくなる。しかし， $\alpha_{p} \leq 0.02$ とはダンパーの塑性化により吸収 したエネルギーが入力エネルギーEに対して僅か $2 \%$ 以下，つまり全 層で概䄈弾性応答と見なせる範囲であり (図 D 参照)，現実的には， 予測精度の低下が問題とならない範囲である。よって, ダンパーの 累積損傷評価を行なう必要がないため, 予測精度が低下しても現実 的には問題とならないと考えることができる。

以上より, 本論文で提案した風応答時の損傷集中指数 ${ }_{d} n_{W i}$ (式(23)) を用いることで, 変動成分に対する風応答時のダンパーの累積損傷 分布 $1 / d_{d} \gamma_{i}$ を, ダンパーのエネルギー分担率 $\alpha_{p}$ が 0.02 より大きい範 囲で高精度に予測でき， $\alpha_{p}$ が増加するほど予測值精度が高くなるこ とがわかった。この傾向がパラメータの差異による影響を殆ど受け ないことも確認された。よって, 予測精度が十分に高くかつダンパ 一の累積損傷評価が必要となる $\alpha_{p}>0.02$ を本手法の適用範囲とする。 なお，本論文では精度検証のために， $d n_{W i}$ を算出する際に弾塑性モデ ルによる時刻歷応答解析結果を用いたが，3.1節で述べたスペクトル モーダル解析による弾性モデルでの応答值を用いることで, ダンパ 一の累積損傷分布を, 時刻歴応答解析結果を用いずに $\alpha_{p}>0.02$ の範 囲で高精度に予測できることを確認している ${ }^{25), 26) 。 こ れ に つ い て は ~}$ 別紙にて詳細に報告する予定である。

\section{5. まとめ}

本論文では，エネルギーの釣合に基づく履歴減衰型ダンパー（以 下，ダンパーと呼ぶ）を有する超高層制振建物の風応答時における ダンパーの累積損傷予測手法を構築することを目的とし, 変動成分 風力が作用した際の, 累積損傷の予測に必要な最適降伏せん断力倸 
数分布 $\bar{\alpha}_{W i}$ や損傷集中指数 ${ }_{d} n_{W i}$ を新たに提案した。以下に, 得られた 知見を示す。

（1）弾性モデルにおける最大応答せん断力係数分布から，風応答時 における最適降伏せん断力係数分布 $\bar{\alpha}_{W i}$ を評価できることを確 認した。風応答時における最適降伏せん断力係数分布は, 地震 応答時の最適降伏せん断力係数分布と異なることがわかった。

(2) $\bar{\alpha}_{W i}$ は辺長比および減衰定数の差異による影響は小さいが, 風 力およびフレームとダンパーの剛性分布の差異による影響を受 けることがわかった。

（3）風力, 辺長比, 減衰定数, 剛性分布および第 1 層のダンパーの 降伏せん断力係数 ${ }_{d} \alpha_{y 1}$ に関係なく, スペクトルモーダル解析よ り予測した $\bar{\alpha}_{W i}$ を用いてダンパーの降伏せん断力を設定するこ とで, 弾塑性風応答解析結果より求めたダンパーの累積損傷分 布 $1 / d \gamma_{i}$ は, 累積損傷分布が全層で等しくなる基準状態の理論值 と精度よく一致していることが確認できた。これによりスペク トルモーダル解析を用いた, 風応答時における最適降伏せん断 力係数分布 $\bar{\alpha}_{W i}$ の予測手法の妥当性を示すことができた。

(4) 本論文で提案した風応答時の損傷集中指数 ${ } n_{W i}$ を用いることで, 風応答時におけるダンパーの累積損傷分布 $1 / d_{d} \gamma_{i}$ を高い精度で 予測できることを確認した。1 $1 / d \gamma_{i}$ の予測值精度は, ダンパーの 塑性化が大きくなるほど高くなる。一方, 入力エネルギーに対 してダンパーの吸収エネルギー量が $2 \%$ 以下となる, ダンパーが 殆ど塑性しない概ね弾性応答と見なせる範囲では，予測精度は 低下するものの, ダンパーの累積損傷を予測する上では事実上 問題とならない。

以上より，履歴減衰型ダンパーを有する超高層制振建物の風外力 の変動成分に対するダンパーの累積損傷分布の予測手法を構築でき たものと考える。

\section{謝辞}

本研究は, 神奈川大学工学研究所大熊武司客員教授, (株) 泉創建 エンジニアリング, (株) 日建設計, 東京理科大学北村研究室, 東京 工業大学佐藤研究室による新耐風設計法研究会の成果の一部です。 特に，本研究を進めるにあたり，大熊武司客員教授，（株）泉創建工 ンジニアリングの丸川比佐夫博士, 片桐純治博士からご意見を賜り ました。ここに記して，感謝の意を表します。

\section{参考文献}

1) 平井宏幸, 吉江慶祐, 佐藤大樹, 北村春幸 : エネルギーの釣合いに基づ く変動風力を受ける超高層制振建物の損傷分配評価, 日本建築学会関東 支部研究報告集, pp. 233-236, 2012.3

2) 池上昌志, 佐藤大樹, 吉江慶祐, 佐藤利昭, 北村春幸 : エネルギーの釣 合に基づく多層制振建物の弾塑性風応答における損傷評価, その 1 風 応答時における最適せん断力係数分布の検証, 日本建築学会関東支部研 究報告, pp.241-244, 2015.3

3) 池上昌志, 佐藤大樹, 吉江慶祐, 佐藤利昭, 北村春幸 : エネルギーの釣 合に基づく多層制振建物の弾塑性風応答における損傷評価, その 2 スペ クトルモーダル解析による最適せん断力係数分布予測と損傷予測, 日本 建築学会関東支部研究報告, pp.245-248, 2015.3

4) 日本免震構造協会 : パッシブ制振構造設計・施工マニュアル, 第 3 版, 2013.11

5) 日本建築学会 : 長周期·長時間地震動と超高層建物の対応策-専門家とし て知っておきたいこと, 2013.10

6) 佐藤大樹, 長江拓也, 大内隼人, 島田侑, 北村春幸, 福山國夫, 梶原浩
一, 井上貴仁, 中島正愛, 斉藤大樹, 福和伸夫 : 長周期地震動を受ける 超高層建物の鋼製ダンパーによる制振改修に関する E-ディフェンス振 動台実験, 日本建築学会構造系論文集, 第 76 巻, 第 667 号, pp.1639-1648, 2011.9

7) 大熊武司, 神田順, 田村幸雄 : 建築物の而風設計, 鹿島出版会, 2004.6

8) 池上昌志, 吉江慶祐, 佐藤大樹, 佐藤利昭, 北村春幸 : 弾塑性ダンパー を有する多質点系モデルの風応答時におけるエネルギー特性, 第 23 回 風工学シンポジウム論文集, pp.415-420, 2014.12

9) 辻田修, 早部安弘, 大熊武司, 和田章: 弾塑性構造物の風応答性状なら びにその予測に関する研究, その 2 風方向の振動の場合, 日本建築学 会構造系論文集，第 485 号, pp.25-34, 1996.7

10）吉江慶祐，北村春幸，大熊武司：エネルギーの釣合に基づく平均成分を 有する広带域性変動風力を受ける弾塑性構造物の応答予測手法, 日本建 築学会構造系論文集, 第 608 号, pp.122-128, 2006.10

11) 秋山宏: エネルギーの釣合に基づく建築物の耐震設計, 技報堂出版, 1997

12）北村春幸, 財津和康, 馬谷原伴恵: 主架構の塑性化を考慮した制振構造 物のエネルギーの釣合に基づく応答評価法, 日本建築学会構造系論文集, 第 599 号, pp.71-78, 2006.1

13) 佐藤大樹, 笠井和彦, 田村哲朗: 粘弾性ダンパーの振動数依存性が風応 答に与える影響, 日本建築学会構造系論文集, 第 635 号, pp.75-82, 2009.1

14) 丸川比佐夫, 大熊武司, 北村春幸, 吉江慶祐, 鶴見俊雄, 佐藤大樹 : 風 洞実験に基づく高層建物の多層層風力によるエネルギー入力性状, その 2 矩形高層建築物に作用寸る層風力特性, 日本建築学会大会学術講演梗 概集, B-1, pp.193-194, 2010.9

15) 日本建築学会 : 建築物荷重指針·同解説, 2004.6

16) 平井宏幸, 吉江慶祐, 佐藤大樹, 片桐純治, 鶴見俊雄, 北村春幸, 大熊 武司: 風洞実験より得られた層風力のサンプル数が高層建築物の時刻歴 風応答評価に及ぼす影響, 日本建築学会技術報告集, 第 18 巻, 第 39 号, pp.489-494, 2012.6

17) 平井宏幸, 吉江慶祐, 佐藤大樹, 鈴木悠也, 北村春幸 : 変動風力を受け る超高層建築物の高次モード応答特性, 日本建築学会技術報告集, 第 18 巻, 第 38 号, pp.79-84, 2012.2

18）吉江慶祐，大熊武司，北村春幸，和田章 : 広帯域性の変動風力を受ける 弾塑性構造物の応答変位振幅の確率分布, 日本建築学会構造系論文集, 第 604 号, pp.37-46, 2006.6

19) 小川諒, 吉江慶祐, 佐藤大樹, 佐藤利昭, 北村春幸 : 変動風力を受ける 超高層免震建物の準静的成分の応答予測手法, 日本風工学会論文集, 第 41 巻, 第 2 号, pp.41-47, 2016.4

20) 辻田修, 早部安弘, 大熊武司, 和田章: 弾塑性構造物の風応答性状なら びにその予測に関する研究, その 1 風直角方向振動の場合, 日本建築 学会構造系論文集, 第 481 号, pp.9-16, 1996.3

21）栗林晃司, 佐藤大樹, 北村春幸, 山口路夫, 西本晃治: 実効変形を考慮 した履歴減衰型制振部材を有する鋼構造建物のエネルギーの釣合に基 づく応答予測法, 日本建築学会構造系論文集, 第 76 巻, 第 661 号, pp.543-552, 2011.3

22）渋谷政斗, 佐藤大樹, 佐藤利昭, 北村春幸, 山口路夫, 脇田直弥, 綿貫 雄太 : ダンパーの損傷配分式の主架構とダンパーの剛性分布が異なる場 合への拡張, 日本建築学会大会学術講演梗概集, B-2, pp.773-774, 2015.9

23) 池上昌志, 吉江慶祐, 佐藤利昭, 佐藤大樹, 北村春幸 : 変動風力を受け る多質点弾塑性建物を用いた等価線形化手法の提案, 日本建築学会大会 学術講演梗概集, B-2, pp.689-690, 2014.9

24) 高橋誠, 秋山宏 : 地震時における柔剛混合構造せん断型多層骨組の損傷 集中特性, 日本建築学会構造系論文集, 第 536 号, pp.63-70, 2000.10

25) 池上昌志, 佐藤大樹, 吉江慶祐, 佐藤利昭, 北村春幸 : 多層制振建物を 用いた風応答の損傷集中指数の予測手法の提案, 日本建築学会大会学術 講演梗概集, B-2, pp.771-772, 2015.9

26) 佐藤大樹, 池上昌志, 平井宏幸, 吉江慶祐, 佐藤利昭, 北村春幸 : 変動 風力を受ける履歴型ダンパーを有する超高層制振建物のエネルギーの 釣合に基づく累積損傷予測，第 11 回日中建築構造技術交流会論文集， pp.164-173, 2015.10

\section{付録 $A$ 基準状態の理論値の導出}

${ }_{d} \alpha_{y i}$ が最適降伏せん断力係数分布 ${ }_{d} \bar{\alpha}_{i}$ に一致する場合, 寸なわち式(18b)の ${ }_{d} p_{i}$ が 1 となる時, 式(17)に式(18a)を代入することにより, ダンパーの累積損傷分 布 $1 /{ }_{d} \gamma_{i}$ は次式のように表現される。 


$$
\frac{1}{{ }_{d} \gamma_{i}}=\frac{{ }_{d} W_{p i}}{\sum_{j=1}^{N}{ }_{d} W_{p j}}=\frac{\left(\sum_{n=i}^{N} \frac{m_{n}}{M}\right)^{2} \cdot{ }_{d} \bar{\alpha}_{i}^{2} \cdot \frac{d k_{1}}{{ }_{d} k_{i}}}{\sum_{j=1}^{N}\left\{\left(\sum_{n=i}^{N} \frac{m_{n}}{M}\right)^{2} \cdot{ }_{d} \bar{\alpha}_{j}{ }^{2} \cdot \frac{d k_{1}}{{ }_{d} k_{j}}\right\}}
$$

一方， ${ }_{d} \bar{\alpha}_{i}$ は次式で表される。

$$
{ }_{d} \bar{\alpha}_{i}=\frac{{ }_{d} \alpha_{y i}}{{ }_{d} \alpha_{y 1}}=\frac{{ }_{d} Q_{y i}}{\sum_{n=i}^{N} m_{n} \cdot g} / \frac{{ }_{d} Q_{y 1}}{\sum_{n=1}^{N} m_{n} \cdot g}
$$

式(A2)を式(A1)に代入することで, 基準状態 $1 / d \gamma_{0 i}$ の理論值（式(6)）が次式の ように導出される。

$$
\begin{aligned}
& \frac{1}{{ }_{d} \gamma_{i}}=\frac{\left(\sum_{n=i}^{N} \frac{m_{n}}{M}\right)^{2} \cdot\left(\frac{{ }_{d} Q_{y i}}{\sum_{n=i}^{N} m_{n} \cdot g} / \frac{{ }_{d} Q_{y 1}}{\sum_{n=1}^{N} m_{n} \cdot g}\right)^{2} \cdot \frac{{ }_{d} k_{1}}{d k_{i}}}{\sum_{j=1}^{N}\left\{\left(\sum_{n=j}^{N} \frac{m_{n}}{M}\right)^{2} \cdot\left(\frac{{ }_{d} Q_{y i}}{\sum_{n=j}^{N} m_{n} \cdot g} / \frac{{ }_{d} Q_{y 1}}{\sum_{n=1}^{N} m_{n} \cdot g}\right)^{2} \cdot \frac{{ }_{d} k_{1}}{d k_{j}}\right\}} \\
& =\left\{\left(\frac{{ }_{d} Q_{y i}}{{ }_{d} Q_{y 1}}\right)^{2} \cdot\left(\frac{{ }_{d} k_{1}}{{ }_{d} k_{i}}\right)\right\} /\left\{\sum_{j=1}^{N}\left(\frac{{ }_{d} Q_{y j}}{{ }_{d} Q_{y 1}}\right)^{2} \cdot\left(\frac{{ }_{d} k_{1}}{{ }_{d} k_{j}}\right)\right\}
\end{aligned}
$$

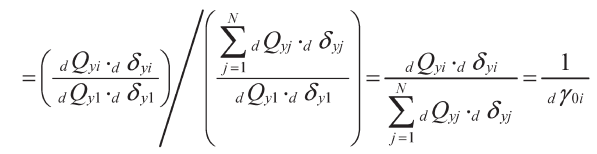

\section{付録 B ダンパーの最適降伏せん断カ}

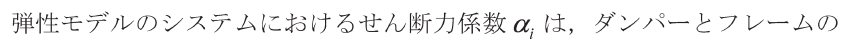
負担せん断力を考慮することにより次式で表される。

$$
\begin{aligned}
\alpha_{i} & =\frac{Q_{i}}{\sum_{j=i}^{N} m_{j} \cdot g}=\frac{{ }_{d} Q_{i}++_{f} Q_{i}}{\sum_{j=i}^{N} m_{j} \cdot g}=\frac{{ }_{d} k_{i} \cdot d}{\sum_{i} \delta_{f} k_{i} \cdot d} \delta_{i} \\
\sum_{j=i}^{N} m_{j} \cdot g & \frac{{ }_{d} Q_{i}}{\left(\sum_{j=i}^{N} m_{j} \cdot g\right)} \cdot\left(\frac{{ }_{d} k_{i}+{ }_{f} k_{i}}{{ }_{d} k_{i}}\right)={ }_{d} \alpha_{i}\left(\frac{k_{i}}{{ }_{d} k_{i}}\right)
\end{aligned}
$$

ここで, ${ }_{d} Q_{i}: i$ 層のダンパーの最大応答せん断力, ${ }_{f} Q_{i}: i$ 層のフレームの最 大応答せん断力, ${ }_{d} \delta_{i}: i$ 層におけるダンパーの最大層間変位, ${ }_{d} \alpha_{i}: i$ 層のダ ンパーのせん断力係数を表す。

弾性モデルにおけるシステムのせん断力倸数分布 $\bar{\alpha}_{i}$ は, ダンパーのせん断 力保数分布 ${ }_{d} \bar{\alpha}_{i}$ を用いて下式で表される ${ }^{21), 22)}$

$$
\overline{\alpha_{i}}=\frac{\alpha_{i}}{\alpha_{1}}={ }_{d} \alpha_{i}\left(\frac{k_{i}}{{ }_{d} k_{i}}\right) /{ }_{d} \alpha_{1}\left(\frac{k_{1}}{{ }_{d} k_{1}}\right)={ }_{d} \bar{\alpha}_{i}\left(\frac{k_{i}}{{ }_{d} k_{i}}\right) /\left(\frac{k_{1}}{{ }_{d} k_{1}}\right)
$$

式(B2)を $\bar{\alpha}_{i}$ について解くことで式(19)が導出される。この時, $i$ 層のダンパ 一の降伏せん断力 ${ }_{d} Q_{y i}$ は ${ }_{d} \bar{\alpha}_{i}$ を用いて次式より算出される。

$$
{ }_{d} Q_{y i}={ }_{d} \alpha_{y 1} \cdot d \bar{\alpha}_{i} \cdot \sum_{j=i}^{N} m_{j} \cdot g
$$

式(19)を式(B3)に代入し， $\bar{\alpha}_{i}$ を風応答時の最適せん断力係数分布 $\bar{\alpha}_{W_{i}}$ に変換 することで, 風応答時における基準状態を満足するダンパーの最適降伏せん断 力 ${ }_{d} Q_{y 0 i}$ は式(7)となる。

\section{付録 C 最適分布での累積損傷予測精度}

横軸をダンパーのエネルギー分担率 $\alpha_{p}$ (式(24)), 縦軸を予測の平均誤差 $R_{1 / d \gamma}$ （式(24)）とし, 最適分布における計 216 ケース（=風力入力方向 : 2 種類 ( 風方向風力, 風直交方向風力) $\times$ 辺長比 $D / B: 3$ 種類 $(1.0,2.0,3.0) \times$ 減衰定数 $1 h: 3$ 種類 $(0.01,0.02,0.05) \times$ model $: 4$ 種類 (F1D1, F1D2, F2D1, F2D2 $) \times{ }_{d} \alpha_{y 1}: 3$ 種類 $(0.01,0.02,0.04)$ の結果を図 C に示す。図 Cより, ダンパーの降伏せん断力を最適分布とした場合, パラメータおよびエネルギー

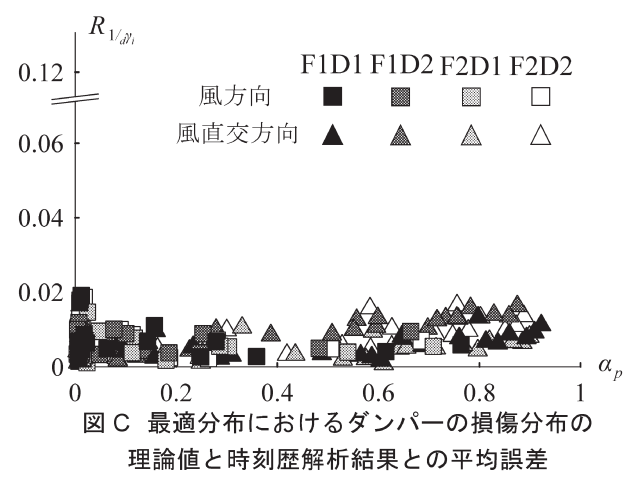

分担率 $\alpha_{p}$ によらず，スペクトルモーダル解析により求めた $\bar{\alpha}_{W i}$ を用いてダン パーのせん断力を決定した時刻歴応答解析結果は, 基準状態 $1 r_{d} \gamma_{0 i}$ の理論值に 良く一致することが確認できる。また，ダンパーの降伏せん断力分布を最適分 布と異なる場合とした予測結果（図 12）と比較すると，いずれの $\alpha_{p}$ において も最適分布を用いた場合（図 C）の方が，予測精度が高いこともわかる。

付録 D エネルギー吸収分担

本論文で用いる解析パラメータにおけるエネルギー吸収分担を確認する。図 $\mathrm{D}$ に, 縦軸をダンパーのエネルギー分担率 $\alpha_{p}$ (式(24)), 横軸を第 1 層のダン パーの最大塑性率 ${ }_{d} \mu_{1}$ として図示する。 ${ }_{d} \mu_{1}$ は式(D1)を用いて算出した。

$$
{ }_{d} \mu_{1}={ }_{d} \delta_{1} /{ }_{d} \delta_{y 1}
$$

ここで, ${ }_{d} \delta_{1}$ : 第 1 層のダンパーの最大層閒変位, ${ }_{d} \delta_{y 1}$ : 第 1 層のダンパーの 降伏変位を表す。

図 D に計 864 ケース (=風力入力方向 : 2 種類 (風方向風力, 風直交方向 風力 $) \times$ 辺長比 $D / B: 3$ 種類 $(1.0,2.0,3.0) \times$ 減衰定数 $h: 3$ 種類 $(0.01$, $0.02,0.05) \times$ model : 4 種類 (F1D1, F1D2, F2D1, F2D2) × ダンパーの降伏 せん断力分布 ${ }_{d} Q_{y i} l_{d} Q_{y 1}: 4$ 種類 (最適分布, 3 段階分布, 2 段階分布, 1 段階 分布） $\times_{d} \alpha_{y 1}: 3$ 種類 $\left.(0.01,0.02,0.04)\right)$ の解析結果を示す。図 Dより, 第 1 層のダンパーの最大塑性率 ${ }_{d} \mu_{1}$ が大きくなると, ダンパーのエネルギー分担 率 $\alpha_{p}$ が増大寸る傾向を確認できる ${ }^{8)}$ 。また, $\alpha_{p}$ は風力, 辺長比 $D / B$, model および ${ }_{d} \alpha_{y 1}$ の差異による影響は小さく, 減衰定数 ${ }_{1} h$ および ${ }_{d} \mu_{1}$ の差異による 影響が大きいこともわかる ${ }^{8)}$ 。一方で, ダンパーの降伏せん断力分布の差異に よる $\alpha_{p}$ への影響は小さいことが確認できる。

図 D の拡大図に着目すると, 第 1 層のダンパーの最大塑性率が小さい ${ }_{d} \mu_{1}$ <2.0）において， $\alpha_{p}$ は極めて小さいことが確認できる。この範囲では，本論 文における応答の評価時間 $600 \mathrm{~s}$ においてダンパーが塑性化するものの, その 時間は短いため, 塑性化により吸収するエネルギーは極めて小さいと判断でき る。つまり, ダンパーの累積損傷を評価する必要がない領域であり, 予測精度 の低下は問題とならない。

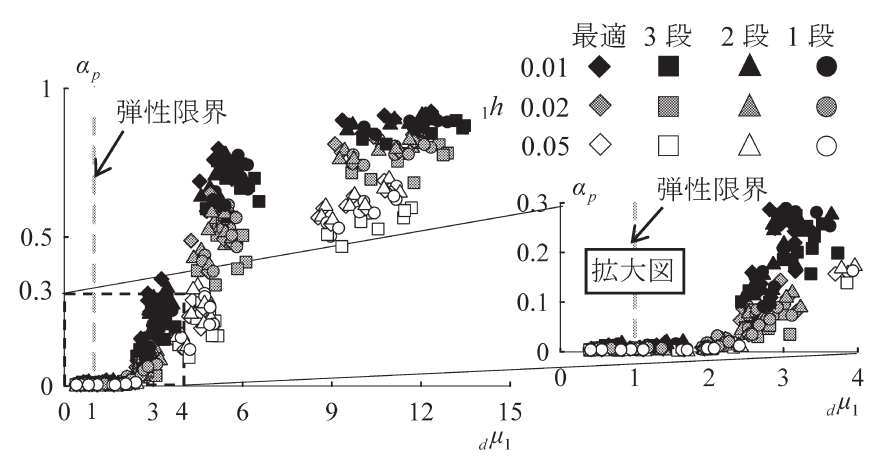

図 D ダンパーの最大塑性率とエネルギー吸収分担の関係 


\title{
CUMULATIVE DAMAGE PREDICTION FOR PASSIVE CONTROLLED HIGH-RISE BUILDING WITH HYSTERETIC DAMPERS ON WIND-INDUCED RESPONSE
}

\author{
Daiki SATO ${ }^{* 1}$, Masashi IKEGAMI*2, Hiroyuki HIRAI*3, \\ Keisuke YOSHIE ${ }^{* 4}$, Toshiaki SATO ${ }^{* 5}$ and Haruyuki KITAMURA *6 \\ ${ }^{* 1}$ Assoc. Prof., FIRST, Tokyo Institute of Tech., Dr.Eng. \\ ${ }^{* 2}$ MAEDA Corporation, M.Eng. (Former Grad. Stud., Tokyo Univ. of Science) \\ *3 TODA Corporation, M.Eng. (Former Grad. Stud., Tokyo Univ. of Science) \\ ${ }^{*}$ General Manager, Structural Engineering Section, Nikken Sekkei Ltd., Dr.Eng. \\ *5 Assoc. Prof., Faculty of Human-Environmental Studies, Kyushu Univ., Dr.Eng. \\ ${ }^{* 6}$ Prof., Dept. of Architecture, Tokyo Univ. of Science, Dr.Eng.
}

An energy balance-based design method for earthquake-induced response of building has been proposed by Dr. Akiyama. This method is very useful for evaluation of the cumulative damage. However, an energy balance-based design method for the wind-induced response of buildings has not been established yet. In this study, we develop a prediction method based on energy balance for the wind-induced cumulative damage to hysteretic dampers installed in a high-rise building. A new optimum yield shear force coefficient distribution and damage concentration factor for the prediction of damage caused by wind-induced response are proposed in this paper. The validity of this method is confirmed by comparing the results with time history analysis results by using a multi-degree-of-freedom model having hysteretic dampers.

In Chapter 2, many time history analyses carried out to evaluate the optimum yield shear force coefficient distribution on wind-induced response. It is verified that the optimum yield shear force coefficient distribution on wind-induced response can be estimated from the maximum response shear force coefficient distribution in the elastic model. In addition, the optimum yield shear force coefficient distribution on wind-induced response shows a feature different from distribution on the earthquake-induced response.

In Chapter 3, we present a new method to calculate the optimum yield shear force coefficient distribution on wind-induced response by using spectrum modal analysis instead of time history analysis. The proposed spectrum modal analysis considers not only the effect of resonant response in the first mode but also the background wind-induced response. The predicted cumulative damage distribution by this optimum yield shear force coefficient distribution agrees well with the theoretical cumulative damage distribution.

In Chapter 4, we propose a new damage concentration factor on wind-induced response. This damage concentration factor is determined from many time history analysis results, and it is larger than the damage concentration factor on earthquake-induced response. The cumulative damage of the damper in the wind-induced response is predicted by using the proposed optimum yield shear force coefficient distribution and damage concentration factor. The validity of this prediction method is confirmed by comparing with many time history analysis results using the multi-degree-of-freedom model with hysteretic dampers. The predicted cumulative damage distribution of dampers on wind-induced response agrees well with the time history analysis results. 